\title{
RESEARCH ON THE FUNCTIONING OF ETHNOGRAPHIC VOCABULARY IN THE SPEECH OF STUDENTS
}

\author{
Kholmatova Dilorom Abdusamiyevna \\ Independent researcher $(\mathrm{PhD})$, teacher of Russian language, department of "Uzbek language and literature", Fergana Polytechnic \\ Institute, 150107, Fergana, st. Fergana, 86, Uzbekistan. \\ *E-mail: dilya.holmatova@gmail.com; ORCID: 0000-0001-9137-3248
}

\begin{abstract}
This article reveals topical issues of the study of ethnographic materials at the present stage and ethnographicisms in the speech of student youth, describes the results of the questionnaire survey in the process of ascertaining the level of knowledge of students of ethnographic vocabulary and its functioning and use in the speech activity of students of the direction "Russian as a foreign language" philological faculty. Aim. The aim of this article is focused, first of all, on students' independent acquisition of information not only in the professional field from original foreign-language sources but also knowledge from different areas of life. Various information, including ethnographic format, expanding the horizons of student youth, enriching it with relevant knowledge, in turn, is associated with the problems of the comprehensive development of the individual in general, and professional self-development, in particular. Methods. Descriptive and comparative research methods, survey, observation and interview methods are used, which can be applied in the study of the Russian language and ethnographic terms. Results. The results of questionnaires and observations can serve as an important source for future educational and search, linguistic, scientific, methodological and other research. As a result of the research, it was revealed that students do not know enough ethnographic terminology. The main thing is that any attempt to identify and assimilate students of ethnographic terminology will have a positive impact on such internal personal factors as spiritual and cultural education, national values, mentality and outlook of students. Conclusions. The study of the use of ethnographic materials by students in the study of Russian as a foreign language at the university showed the relevance and topicality of the use of ethnographic materials for the development and improvement of the Russian speech of student youth. It was revealed that the conclusions drawn in the process of questioning and interviewing students will diversify the content of Russian language classes at the university, stimulate students to study the Russian language, as well as the widespread use of ethnographic words by student youth in the Russian speech stream.
\end{abstract}

Keywords

ethnographic terminology; ethnos; ethnology; vocabulary; interethnic communications; questioning; vocabulary.

Article Received: 18 October 2020, Revised: 3 November 2020, Accepted: 24 December 2020

\section{Introduction}

In the context of globalization, integration of sciences, changes taking place in the sociopolitical life of society, the younger generation shows an objective interest in various fields of knowledge, including ethnographic. In this regard, in modern linguistic and methodological science, studies devoted to the problems of ethnography, its features, ethnographic terminology, as well as its functioning and use in speech are relevant.

\section{Literature Review}

Studying the problem, reviewing and analysing the scientific literature on the research topic shows that in the methodology of teaching Russian as a foreign language based on the use of ethnographic materials, there are several cognitive-pragmatic issues that need to be addressed.

At the same time, it is important to note that research in this direction has been conducted for a long time. The issue of using ethnographic information in the classes on the Russian language at the university is given some attention, especially by the scientists-authors of educational literature on ethnology (V.V. Pimenova, V.E. Markova, S.A. Tokarev), who continue the traditions of representatives of the Russian ethnographic school (L. S. Perepyolkina, T. V. 
Mastyugina, T. G. Grushevitskaya, A. P. Sadokhina).

In the last decades of the twentieth century, many researchers in Uzbek linguistics also began to address this issue, including Arifkhanova Z.Kh., Shoniyozov K., Doniyorov A.Kh., Alimova D.A., Zununova G.Sh., etc.

However, their research focuses on the ethnography and ethnology of Uzbekistan, its history, linguistic analysis of ethnological terms, but does not touch upon methodological issues, i.e. technologies of using ethnographisms in the process of the speech-thinking activity. It should also point to the existence of scientific works of a theoretical and general methodological nature, which, as you know, are precisely the basic component of ethnographic work. Here it is necessary to note the studies of the ethnocultural plan, written mostly from a general philosophical standpoint. With all this, these works are not directly related to the methodology of teaching and learning ethnography, however, they still have a certain influence on its methodology, since they give an idea of some guidelines for methodological researchers specializing in ethnographic problems, showing by what basic criteria the development of the material and spiritual culture of one or another ethnic group.

\section{Materials and methods}

As you know, at present the pedagogical vocabulary of the teacher has increasingly used the concept of "ethnography", "ethnographic terminology", "ethnographic materials", which speaks of the relevance and popularity of ethnographic science and in the educational process.

Of course, the goals of the training are focused, first of all, on the independent acquisition of information by students not only in the professional field from original foreign-language sources but also knowledge from different areas of life. Various information, including ethnographic format, expanding the horizons of student youth, enriching it with relevant knowledge, in turn, is associated with the problems of the all-round development of the individual in general, and professional self-development, in particular. From the first days of study, university students have to master a large number of new scientific terms, specific phrases and phrases of scientific speech, including ethnographic vocabulary, which is saturated with ethnographic content necessary for full-fledged communication of the young generation on various topics of our time.

It must be admitted that the new phase of the formation of this direction is considered within the framework of the linguistic and cultural approach to language teaching and is mainly focused on the formation of lexical skills based on ethnographic materials.

The study of Russian as a foreign language in the national groups of universities in Uzbekistan on the basis of ethnographic materials will allow solving the problems of forming a cognitivepragmatic consciousness of a linguistic personality. Of course, the need to identify the world specifically in linguistic ethnographic diversity, along with the main ethnic units, makes it possible to consider the uniqueness and specificity of the language of each ethnos, linguistic contacts and inter-ethnic communications. It should be noted that the lexical composition of the ethnolanguage is expanding, enriched, and also the vocabulary of the languages in contact is replenished with ethnographic terminology. All this, no doubt, speaks of its importance.

Of course, at present, not all ethnographic materials have been collected and systematized by researchers in full, and the ethnographic terminology associated with the nominations of everyday objects (household utensils, dishes, clothes, shoes, jewellery, food, etc.) has not been sufficiently studied. In view of the frequency and diversity of ethnographic vocabulary, its wide use in a colloquial speech by young people and their lack of awareness of the life and culture of the ethnic groups in contact (in our case, Russian and Uzbek). We believe that the study of this issue in the methodological aspect (pragmatic plan) is of great interest, relevance and significance, which 
confirms the relevance of the research topic. Improving the general culture of student youth, her study of various special disciplines, speaks of her desire to master comprehensive knowledge, including ethnographic. In this regard, in order to satisfy the needs and demands of the younger generation, it is important, in our opinion, their knowledge of ethnographic materials as well. For ignorance, for example, of certain ethnographic lexemes, i.e. ethnographic terms can lead to misunderstanding, interpretation or distorted use in the communication process.

Of course, we were faced with the task of not only studying the theoretical provisions, concepts, ideas and views of Uzbek, Russian and foreign scientists about ethnography and ethnology, as well as ethnographic terms but also acquainting students with ethnographic terminology for the purpose of ethnolinguistic education. In this regard, we have attempted to develop a system of work on the widespread use of ethnographic material, the core of which is ethnographic vocabulary, to activate it in interpersonal communication. With all this, this system is based on the phased introduction of ethnographisms that are frequency in speech practice. The practical significance of the work lies in the development of guidelines, proposals that will be embodied in the university practise of teaching Russian as a foreign language, can be used in intercultural contacts of various ethnic groups living in the same territory; when compiling ethnographic dictionaries of various types (explanatory, translation, etc.) for higher education, the wide and conscious use of ethnographic concepts in speech practice, as well as in the process of translating ethnographic materials from one language into another (in our case, from Russian into Uzbek and vice versa) for lingua didactic purposes, as well as comparative studies of different systemic languages (Russian and Uzbek languages) in the future.

The results of this research can be used in the preparation of textbooks, reference books, as well as in the reading of special courses, seminars, elective disciplines, in lexicographic practice.
Based on the set objectives of the study, we applied both the method of semantic analysis to explain the meaning of ethnographicisms, and expeditionary (field), sociological and pedagogical (conversations and questionnaires with students, studying the experience of teachers).

The study of materials of modern ethnography (ethnosociological and ethnopsychological research), the study of scientific works of ethnographers, ethnologists (journalistic materials, travel notes, folklore and literary texts, etc.) determined the problem of the significance of the material under study for the educational process. At the same time, we used various, which can be called "living" materials, about direct daily contacts of the "titular ethnic group" and representatives of different ethnic groups living in the same territory, in particular, Uzbekistan. In this study, real observations of the linguistic reactions of the contacting ethnic groups in various life situations, of the speech actions used by ethnic groups in communication, the manner of expressing and interpreting all kinds of events in the environment and personal behaviour became valuable materials. The main object of attention of this study is the issue related to the linguistic characteristics of the Russian and Uzbek ethnic groups, their relationships, both in everyday life and in society. The historiographic analysis of the problem made it possible to formulate predictive characteristics of further work, to determine the knowledge base on which it is necessary to rely in the research, which allowed us to single out the following sections:

1. Property or object section (food and methods of its production; household forms; dishes and utensils; tools; weapons; jewellery; clothes and shoes; houses and dwellings).

2. Social structure (marriage and family; social unions).

3. Spiritual culture (language and religion; morality; art; poetry; writing) $[9,91]$.

It is well known that ethnography is an integral disciplinary part of historical and philological science, which can be used with great success in 
the methodology of teaching languages, including Russian. To understand the essence of current ethnographic research, it is important, in our opinion, to address the following issues:

- Who and at what research-level carried out ethnographic searches for materials regarding the last period (XX centuries)?

- Who can be called the founders of the Russian and Uzbek ethnographic schools?

- What questions did they consider the most urgent and significant?

- What problems remained outside the field of vision of researchers?

- What issues have not been resolved?

The search for answers to them makes it possible to turn to the topic of using the materials of ethnographic science, which is quite relevant and very significant in practical terms.

At the initial stage of the process of ethnographic education of student youth, we consider it important that students get acquainted with the general theoretical issues considered by ethnographic science, then with educational text material of a linguistic and cultural nature, which is saturated with ethnographic vocabulary. The study of the material begins with an introduction to the definition of an ethnographic incomprehensible and unfamiliar concept and term. Since in ethnographic science, as, indeed, in other sciences, one can come across such words and expressions that are interpreted differently than in the generally accepted presentation. In this regard, we offered students to work on frequency ethnographic terms that are widely used in the everyday speech of an ethnic group, in their speech practice. We believe that students for fullfledged intercultural communication, first of all, should enrich their vocabulary to get to know more closely the life and life of the ethnic groups in contact, garments, household utensils, customs and traditions that differ in national flavour, know to a certain extent speech etiquette, etc., because a university course involves the integration of sciences (linguistics, literary criticism, history, geography, economics, ethnography, etc.). In this regard, the requirements for the standard and working program, its content, information richness and relevance in relation to the issue we are researching, are increasing [8]. One of the constructive ways of teaching ethnography in practical classes of Russian as a foreign language is a way of searching for ethnographic materials saturated with ethnographic vocabulary.

In the collection "Sources and Methods of Studying Small Groups in Ethnography" by the Russian ethnographer V.A. Kozmin, it is indicated that the field method of work is effective research, with the help of which one can find the basic material on ethnography. An interesting method is used direct observation. The design of this method allows you to divide the types of fieldwork into observation, study, survey, questioning. Observation materials can be recorded in special diaries and notebooks, video and audio recordings, photographs and all kinds of graphic sketches. All the collected information is the main ethnographic material [12, 4].

We used an expeditionary method of work to collect ethnographic materials by field, i.e. research by staying in the Russian ethnic environment not only in the places of residence of the titular nation (Russia) but also on the territory of Uzbekistan, which provided fertile and valuable material on the topic of research [1-3].

This method and way of searching personally by the students for "living" ethnographic material arouses great interest among student youth, motivates them to study ethnographic materials not only in the cognitive and pragmatic terms but also in the spiritual and moral educational format. The beginning of the work was a clear distribution of tasks for the search and collection of the necessary ethnographic material. At the same time, tasks are offered to take into account the interests and desires of students. For example, we offered the first group a task to search for materials on the topic: "Clothes, shoes, jewellery of the Russian people", the other - "Dishes and household utensils", the third - "Russian national dishes and food", the fourth - Russian speech 
etiquette, fifth - "Tools of Labour, Hunting of the Russian People", etc. [6, 21].

A significant role in the search work is assigned to the description of the nomination of the object, its appearance, use, significance in everyday life or the life of an ethnic group, etc. Students display the material in notebooks and diaries for fieldwork, photo and video recordings, as well as graphic design. This work is of interest to students since the material independently found during search work is transferred directly into the fabric of the classroom, where a heated discussion of the results of field research continues.

Also, in our opinion, at the initial stage of the mini-research work, it is important to explain to students the goals and objectives set by the teacher for working with ethnographic material, in the process of testing the educational project "Studying Ethnology". It is also advisable to use a questionnaire (or questionnaire) so that the student does not switch to another topic. We surveyed with students of 1,2,4,5 courses of the philological faculty of the Kazan (Volga region) Federal University (Russia) and students of $3^{\text {rd }}$ courses of the philological direction of the Moscow State Institute of the Russian Language named after A.S. Pushkin (Russia). During the ascertaining section, 113 students took part in the survey. This questionnaire was compiled for the primary identification of the level of awareness of students about ethnographic terms.

\section{QUESTIONNAIRE}

Participant of the ascertaining section on the topic:

"Knowledge of ethnographic terminology"

Full name of the respondent

Country, university

Direction, faculty, course

Questionnaire:

1. How do you understand the meaning of the following words?

Ethnography

Ethnology

Ethnos

2. Have you heard about these words before?

If yes, please check the sources

When (long ago; only now I found out)

3. Would you like to know what these words mean?

"Yes"

"No"

"I don't know, I didn't think about it"

4. To find out about the meaning of these terms, you use the materials:

1) the Internet

2) dictionaries

3) other sources (which ones?)

Figure 1. Questionnaire.

The total number of respondents 113 students, including 1 course - 21 students,

2 courses - 26 students, 3 courses - 31 students, 4 courses - 15 students, 5 courses - 20 students. The survey data showed the following results (in per cent): 
Table 1. Results 1st question.

\begin{tabular}{|c|c|c|c|c|c|c|c|}
\hline \multirow[b]{2}{*}{ Groups of students } & \multirow{2}{*}{$\begin{array}{l}\text { On the first question } \\
\text { "How do you understand } \\
\text { the meaning of the } \\
\text { following words?" } \\
\text { answered (total students) }\end{array}$} & \multicolumn{2}{|c|}{ Ethnography } & \multicolumn{2}{|c|}{ Ethnography } & \multicolumn{2}{|c|}{ Ethnos } \\
\hline & & 章 & 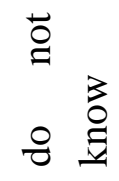 & za & 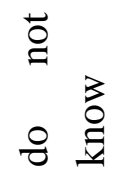 & ב্ & 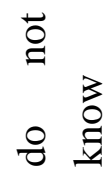 \\
\hline $\begin{array}{l}\text { KFU (Kazan Federal University) } \\
\text { (students of the } 1^{\text {st }} \text { and } 2^{\text {nd }} \\
\text { courses) }\end{array}$ & $100 \%$ & $52 \%$ & $48 \%$ & $37 \%$ & $63 \%$ & $38 \%$ & $62 \%$ \\
\hline $\begin{array}{l}\text { KFU (students of } 4^{\text {th }} \text { and } 5^{\text {th }} \\
\text { courses) }\end{array}$ & $100 \%$ & $42 \%$ & $58 \%$ & $46 \%$ & $54 \%$ & $55 \%$ & $\begin{array}{l}45 \\
\%\end{array}$ \\
\hline $\begin{array}{l}\text { "Moscow State Institute of the } \\
\text { Russian Language named after } \\
\text { A.S. Pushkin" (MSIRL) } \\
\text { (students of } 3^{\text {rd }} \text { courses) }\end{array}$ & $100 \%$ & $45 \%$ & $55 \%$ & $30 \%$ & $70 \%$ & $35 \%$ & $65 \%$ \\
\hline
\end{tabular}

Figure 2. Results of answers to the 1st question.

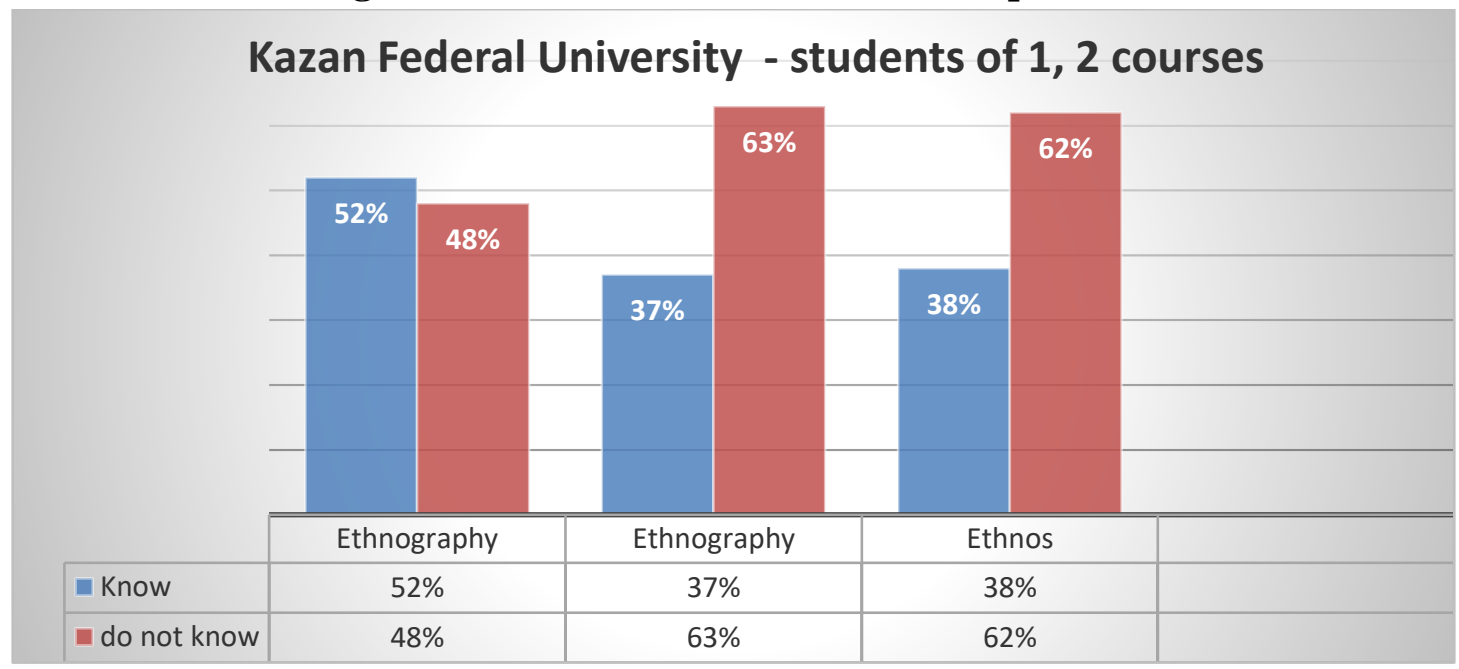

Kazan Federal University - students of 4, 5 courses

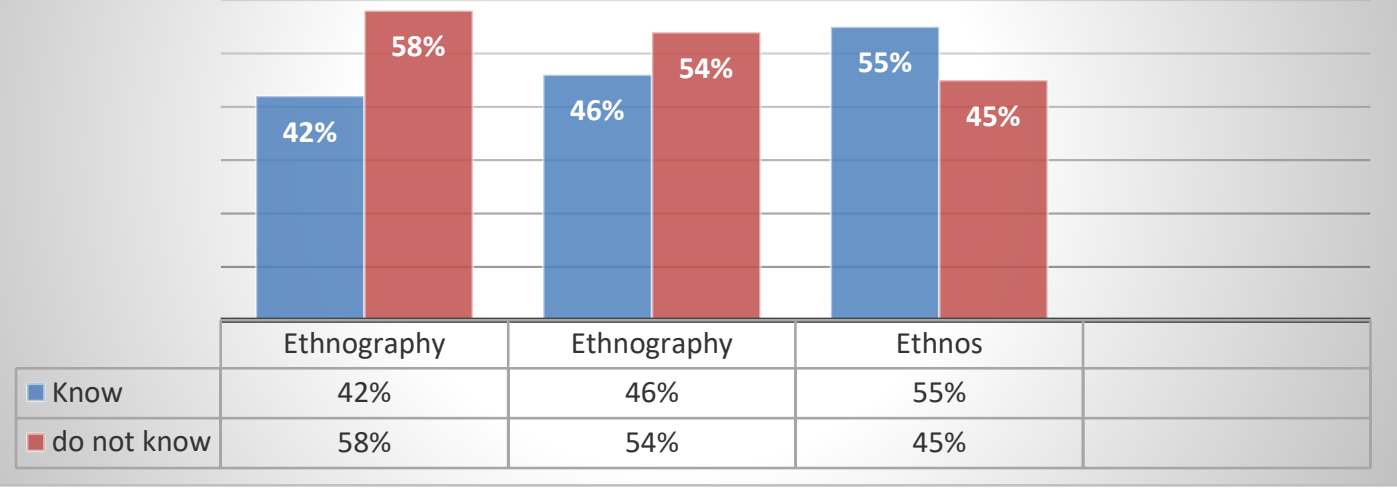




\section{Moscow State Institute of the Russian Language named after A.S. Pushkin - students of $\mathbf{3}$ courses}

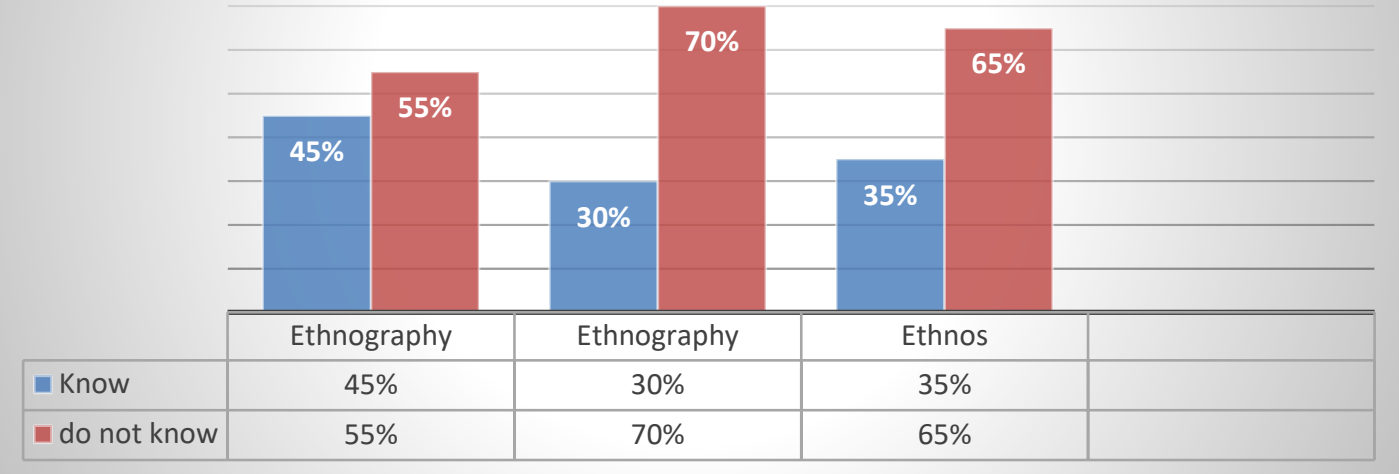

Thus, on the $1^{\text {st }}$ question "How do you understand the meaning of the following words: ethnography,

ethnology, ethnos?" We can conclude that students have little knowledge of these concepts.

Table 2. 2nd question.

\begin{tabular}{|c|c|c|c|}
\hline Groups of students & $\begin{array}{l}\text { On the second } \\
\text { question "Have } \\
\text { you heard about } \\
\text { these words } \\
\text { before?" } \\
\text { answered (total } \\
\text { students) }\end{array}$ & $\begin{array}{l}\text { If "Yes", then check the } \\
\text { sources }\end{array}$ & $\begin{array}{l}\text { when (heard "long ago", } \\
\text { "just now learned") }\end{array}$ \\
\hline $\begin{array}{l}\text { Kazan Federal } \\
\text { University (students of } \\
\text { the } 1^{\text {st }} \text { and } 2^{\text {nd }} \text { courses) }\end{array}$ & $100 \%$ & $\begin{array}{l}\text { Answered "yes" - } 45 \% \\
\text { Sources - classes on the } \\
\text { history and culture of the } \\
\text { peoples of Russia }\end{array}$ & $\begin{array}{l}23 \% \text { - answered they } \\
\text { heard "for a long time" } \\
32 \% \text { - answered "I just } \\
\text { found out" }\end{array}$ \\
\hline $\begin{array}{l}\text { Kazan Federal } \\
\text { University (students of } \\
4^{\text {th }} \text { and } 5^{\text {th }} \text { courses) }\end{array}$ & $100 \%$ & $\begin{array}{l}\text { Answered Yes - } 32 \% \\
\text { Sources - classes in history } \\
\text { and linguistics, books. }\end{array}$ & $\begin{array}{l}36 \% \text { - answered they } \\
\text { heard "for a long time" } \\
32 \% \text { - answered "I just } \\
\text { found out" }\end{array}$ \\
\hline $\begin{array}{l}\text { "Moscow State Institute } \\
\text { of the Russian Language } \\
\text { named after A.S. } \\
\text { Pushkin" (MSIRL) } \\
\text { (students of } 3^{\text {rd }} \text { courses) }\end{array}$ & $100 \%$ & $\begin{array}{l}\text { The answer was "yes" - } 56 \\
\% \\
\text { Sources-textbooks } \\
\text { "Anthropology", "History } \\
\text { of Russia", in classes on } \\
\text { Russian culture }\end{array}$ & $\begin{array}{l}34 \% \text { - answered they } \\
\text { heard "for a long time" } \\
10 \% \text { - answered "I just } \\
\text { found out" }\end{array}$ \\
\hline
\end{tabular}

Figure 3. Results of answers to the 2nd question 
$1^{\text {st }}$ and $2^{\text {nd }}$

courses

Kazan (KFU) -"yes" - 45\% (sources: lessons on the history and culture of the peoples of Russia);

-heard "for a long time" - 23\%;

-"I just found out" - 32\%. $3^{\text {rd }}$ courses

Moscow

(MSIRL)
- "yes" - 56\% (sources: textbooks "Anthropology", "History of Russia", in the classroom on Russian culture);

- have heard "for a long time" - 34\%;

- "I just found out" - $10 \%$. $4^{\text {th }}$ and $5^{\text {th }}$

courses

\section{Kazan (KFU)}

- "yes" - 32\% (sources: lessons in history and linguistics, books)

- have heard "long ago_36\%;

- "I just found out" - $32 \%$.
From this table it should be concluded that the second question "Have you heard before about the concepts of ethnography, ethnology, ethnos?" answered positively:

- students of the $1^{\text {st }}$ and $2^{\text {nd }}$ courses of KFU $45 \%$;

- $\quad$ students of $3^{\text {rd }}$ courses MSIRL $-56 \%$;

- students of $4^{\text {th }}$ and $5^{\text {th }}$ courses of KFU $32 \%$, citing the following sources: classes in history, linguistics, the culture of the peoples of Russia, textbooks on "Anthropology", "History of Russia".

They answered negatively to this question:

- have heard "for a long time" - students of the $1^{\text {st }}$ and $2^{\text {nd }}$ courses of KFU $-23 \%$;

Table 3. 3rd question

\begin{tabular}{|l|l|l|l|l|}
\hline Groups of students & $\begin{array}{l}\text { On the third question } \\
\text { "Would you like to } \\
\text { know what these words } \\
\text { mean?" } \\
\text { answered (total } \\
\text { students) }\end{array}$ & Yes & No & $\begin{array}{l}\text { I don't know, I } \\
\text { didn't think }\end{array}$ \\
\hline $\begin{array}{l}\text { Kazan Federal University (students of } \\
\text { the } 1^{\text {st }} \text { and } 2^{\text {nd }} \text { courses) }\end{array}$ & answered from 100\% & $75 \%$ & $8 \%$ & $17 \%$ \\
\hline $\begin{array}{l}\text { Kazan Federal University (students of } \\
4^{\text {th }} \text { and } 5^{\text {th }} \text { courses) }\end{array}$ & answered from 100\% & $78 \%$ & $3 \%$ & $19 \%$ \\
\hline
\end{tabular}

- students of $3^{\text {rd }}$ courses MSIRL - 34\%;

- students of $4^{\text {th }}$ and $5^{\text {th }}$ courses of KFU $36 \%$;

"I just found out":

- students of the $1^{\text {st }}$ and $2^{\text {nd }}$ courses of KFU $32 \%$;

- students of $3^{\text {rd }}$ courses MSIRL - $10 \%$;

- students of $4^{\text {th }}$ and $5^{\text {th }}$ courses of KFU $32 \%$.

Most of the students answered negatively, which means that these names were previously unfamiliar to them. 


\begin{tabular}{|l|l|l|l|l|}
\hline "Moscow State Institute of the & answered from 100\% & & & \\
Russian Language named after A.S. & & $76 \%$ & $6 \%$ & $18 \%$ \\
Pushkin" (MSIRL) (students of $3^{\text {rd }}$ \\
courses)
\end{tabular}

Figure 4. Results of answers to the third question.

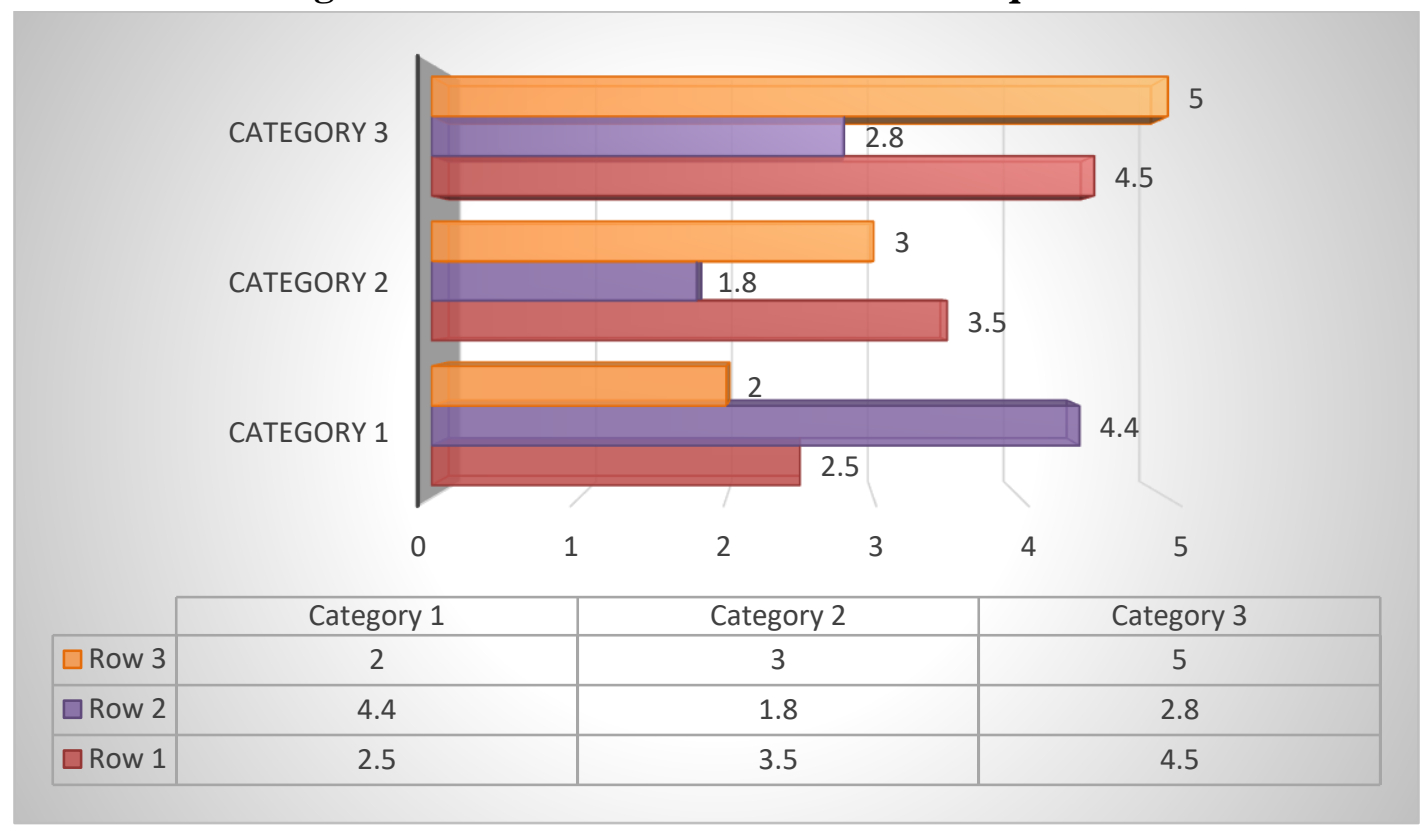

Results of the 3rd question: "Would you like to know what these words mean?" give us the right to draw conclusions that most of the students would like to know and study ethnographic terminology.

Table 4. 4th question

\begin{tabular}{|c|c|c|c|c|}
\hline Groups of students & $\begin{array}{l}\text { On the 4th } \\
\text { question "To find } \\
\text { out about the } \\
\text { meaning of these } \\
\text { terms do you use } \\
\text {..." } \\
\text { answered (total } \\
\text { students) }\end{array}$ & $\begin{array}{l}\text { Internet } \\
\text { materials }\end{array}$ & Dictionaries & $\begin{array}{l}\text { Other } \\
\text { sources } \\
\text { (which } \\
\text { ones?) }\end{array}$ \\
\hline $\begin{array}{l}\text { Kazan Federal } \\
\text { University (students of } \\
\text { the } 1^{\text {st }} \text { and } 2^{\text {nd }} \text { courses) }\end{array}$ & $\begin{array}{l}\text { answered out of } \\
95 \%\end{array}$ & $\begin{array}{l}88 \% \text { will use: } \\
\text { electronic } \\
\text { dictionary, } \\
\text { Wikipedia, } \\
\text { Google Scholar }\end{array}$ & $\begin{array}{l}4 \%, \text { Large } \\
\text { Explanatory } \\
\text { Dictionary of the } \\
\text { Russian } \\
\text { Language by S. } \\
\text { A. Kuznetsov }\end{array}$ & $\begin{array}{l}3 \% \text { - } \\
\text { источник: } \\
\text { учебники; } \\
5 \text { \% - на } \\
\text { вопрос не } \\
\text { ответили } \\
\end{array}$ \\
\hline $\begin{array}{l}\text { Kazan Federal } \\
\text { University (students of } \\
4^{\text {th }} \text { and } 5^{\text {th }} \text { courses) }\end{array}$ & $\begin{array}{l}\text { answered from } \\
100 \%\end{array}$ & $\begin{array}{l}86 \% \text { will use: } \\
\text { electronic } \\
\text { dictionary, }\end{array}$ & $\begin{array}{l}12 \%, \\
\text { dictionaries: D. } \\
\text { N. Ushakov, S. I. }\end{array}$ & $\begin{array}{l}2 \%, \\
\text { sources: } \\
\text { mass media, }\end{array}$ \\
\hline
\end{tabular}




\begin{tabular}{|c|c|c|c|c|}
\hline & & $\begin{array}{l}\text { Runet, } \\
\text { Wikipedia }\end{array}$ & $\begin{array}{l}\text { Ozhegov, V. I. } \\
\text { Dal }\end{array}$ & textbooks \\
\hline $\begin{array}{l}\text { "Moscow State } \\
\text { Institute of the Russian } \\
\text { Language named after } \\
\text { A.S. Pushkin" } \\
\text { (MSIRL) (students of } \\
3^{\text {rd }} \text { courses) }\end{array}$ & $\begin{array}{l}\text { answered from } \\
100 \%\end{array}$ & $\begin{array}{l}80 \% \\
\text { electronic } \\
\text { dictionary, } \\
\text { Wikipedia }\end{array}$ & $\begin{array}{l}15 \% \text { bilingual } \\
\text { dictionary }\end{array}$ & $\begin{array}{l}5 \% \text { sources: } \\
\text { educational } \\
\text { literature } \\
\text { textbooks }\end{array}$ \\
\hline
\end{tabular}

Figure 5. Results of the answers to the 4th question.

\begin{tabular}{|l|}
\hline $\begin{array}{l}1^{\text {st }} \text { and } 2^{\text {nd }} \text { courses } \\
\text { Kazan (KFU) }\end{array}$ \\
\hline - Internet-88\% \\
- Dictionaries - 4\% \\
- other sources (what) -3\% \\
- did not answer the \\
question - 5\% (sources of \\
information:electronic \\
dictionary, Wikipedia, \\
Google Scholar, S. A. \\
Kuznetsov's large \\
explanatory dictionary \\
of the Russian language, \\
textbooks)
\end{tabular}

\begin{tabular}{|l|}
\hline \multicolumn{1}{|c|}{$\begin{array}{c}3^{\text {rd }} \text { courses } \\
\text { Moscow } \\
\text { (MSIRL) }\end{array}$} \\
\hline \multicolumn{1}{|c|}{ The Internet-80\% } \\
- Dictionaries-15\% \\
- other sources \\
(what) - 5\% \\
(information \\
sources: electronic \\
dictionary, \\
Wikipedia, \\
bilingual \\
dictionary, \\
educational \\
literature, \\
textbooks)
\end{tabular}

\begin{tabular}{|l|}
\hline $\begin{array}{c}4^{\text {th }} \text { and } 5^{\text {th }} \\
\text { courses }\end{array}$ \\
Kazan (KFU) \\
\hline - Internet-86\% \\
- Dictionaries-12\% \\
- other sources \\
(what) - 2\% \\
(information \\
sources: electronic \\
dictionary, Runet, \\
Wikipedia, \\
dictionaries: D. N. \\
Ushakov, S. I. \\
Ozhegov, V. I. Dal; \\
mass media, \\
textbooks)
\end{tabular}

From this table it should be concluded that the second question "Have you heard before about the concepts of ethnography, ethnology, ethnos?" answered positively:

- students of the $1^{\text {st }}$ and $2^{\text {nd }}$ courses of KFU $45 \%$;

- $\quad$ students of $3^{\text {rd }}$ courses MSIRL - 56\%;

- students of $4^{\text {th }}$ and $5^{\text {th }}$ courses of KFU $32 \%$, citing the following sources: classes in history, linguistics, the culture of the peoples of Russia, textbooks on "Anthropology", "History of Russia".

They answered negatively to this question:

- have heard "for a long time" - students of the $1^{\text {st }}$ and $2^{\text {nd }}$ courses of KFU - 23\%;

- $\quad$ students of $3^{\text {rd }}$ courses MSIRL - 34\%;
- students of $4^{\text {th }}$ and $5^{\text {th }}$ courses of KFU $36 \%$;

"I just found out":

- students of the $1^{\text {st }}$ and $2^{\text {nd }}$ courses of KFU $32 \%$;

- students of $3^{\text {rd }}$ courses MSIRL - $10 \%$;

- students of $4^{\text {th }}$ and $5^{\text {th }}$ courses of KFU $32 \%$.

Most of the students answered negatively, which means that these names were previously unfamiliar to them.

\section{Results}

In this regard, unfortunately, we believe that today's young people have become less likely to read printed literature of a dictionary-reference 
nature. This also explains the fact that modern technology takes a leading place in the students ' knowledge acquisition. Among the dictionaries in which they can find the information they are interested in, the students named "The Big Encyclopaedic Dictionary", explanatory dictionaries, dictionaries of the Russian language by D. N. Ushakov, S. I. Ozhegov and V. I. Dal, but none of the students named special " Ethnographic dictionaries "or" Dictionaries of ethnographic terms".

The results of this survey and interviews allow us to conclude the insufficient full use of the media, scientific and journalistic literature by students for their conscious understanding of ethnographic terms and the scope of their use. To the question "Would you like to know what these words mean?", most of the students gave a positive answer, which indicates their interest in information and knowledge in the field of ethnography. According to the results of the survey, the following conclusion can be made: students do not have sufficient knowledge of ethnographic terminology. For example, $38 \%$ of students know that the term "ethnology" (Greek

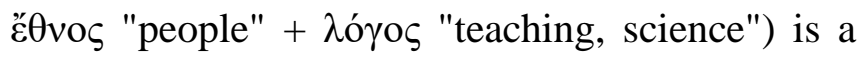
science that studies ethnic processes that imply diverse aspects of the life of peoples (ethnic groups), as well as other ethnic groups.

\section{Discussions}

Along with the survey, we conducted interviews with the help of video recordings on the mobile phone of 34 students of Russian universities listed above. Not all interviewees know the correct meaning of the words "ethnography, ethnology and ethnos". In the analysis, the average score of the level of knowledge of the respondents was derived. The surveyed students (45\%) "heard" these terms before, but do not remember - where and when, or answered that they "did not hear and learned only now" (25\%). They also made the following assumptions about the sources of this information:
1) from the course of history and linguistics (32 $\%)$

2) from the mass media on Russian culture (45 $\%$;

3) books and educational literature ("Anthropology", "History of Russia") (56\%).

Research on the use of the students of the ethnographic materials in the study of Russian as a foreign language in high school showed the relevance and topicality of the use of the materials on Ethnography for the development and improvement of Russian language students.

\section{Conclusion}

It is revealed that the conclusions reached in the process of questioning and interviewing of students, will allow to diversify the content of the lessons of the Russian language in the University, to encourage students to study the Russian language and the extensive use of students ' ethnographic words in the Russian speech stream. We believe that the results of the survey and observations can serve as an important source for conducting educational and search, linguistic, scientific and methodological and other research in the future.

The main thing is that the attempt to identify and assimilate ethnographic terminology by students will have a positive impact on such internal personal factors as spiritual and cultural education, national values, mentality, and worldview of students.

The study of the issue confirmed the importance of ethnographic materials for the development of cognitive abilities of students, enriching their vocabulary with ethnographic terms, their wide and active use in speech practice for direct communication with representatives of the contacted ethnic group, improving the communication process. At the same time, there are several problems in terms of the inclusion/non-inclusion of ethnographisms in the active or passive vocabulary of students.

In our opinion, it is necessary to draw the attention of researchers to several unresolved 
problems regarding the methods of teaching and teaching Russian as a foreign language based on materials on ethnography. As mentioned above, the problem put forward in this study exists insufficiently developed and therefore aroused our research interest.

\section{Acknowledgement}

Authors acknowledge the immense help received from the scholars whose articles are cited and included in references to this manuscript. The authors are also grateful to authors/ editors/publishers of all those articles, journals and books from where the literature for this article has been reviewed and discussed.

\section{References}

[1] Adilova, G. A., \& Suatay, S. K. (2014). Etnografizma as a reflection of the relationship of history of language and culture. Russian Language and Culture in the Mirror of Translation, (1), 517-522.

[2] Apanasenko, E. G. (2009). Russia-EastWest in the Mirror of Russian Ethnonyms: abstract of the dissertation Candidate of Philological Sciences. Vladivostok, 21 p.

[3] Apresyan, Y. D. (1994). Lexical semantics: Synonymic means of the language. Moscow. Science, $367 \mathrm{p}$.

[4] Arifkhanova, Z. H., \& Zununova, G. S. (2006). Ritual and ritual life of the Uzbeks of Tashkent in the conditions of independence. Institute of History of the Academy of Sciences of the Republic of Uzbekistan. p.93.

[5] Berezkina, E. S. (2001). Ethnonymic vocabulary in oral folk poetry. abstract of the dissertation Candidate of Philological Sciences. Orel, 17 p.

[6] Bolshakova N.V. (2001). Ethnonyms and related phenomena in the dictionary of $\mathrm{V}$. Dahl. Materials of the linguistic section of the scientific and methodological conference of PSPI named after S.M. Kirov, dedicated to the 200th anniversary of the birth of V.I. Dahl. Pskov: PSPI. pp. 105-107.

[7] Buzin, V.S. (2007). Ethnography of Russians: Textbook. SPb. 2009. pp.3-5.

[8] Vasiliev, N.L., \& Popovich, T. (2015). The integrative potential of the university course "History of the Russian literary language". Integration of Education, 19 (3 (80)).

[9] Gachev, G. D. (1999). National images of the world. Eurasia is the cosmos of the nomad, farmer and mountaineer (pp. 368368). Institute DI-DIK. Moscow. p.368.

[10] Doniyorov A.Kh. (2003). Historiography of ethnography of independent Uzbekistan (1991-2001) Tashkent. p. 36.

[11] Jane, Z. (2006). Fieldwork ethics in ethnography. Anthropological Forum, St. Petersburg. (5). pp. 169-193.

[12] V.A. Kozmin. (2010). Sources and methods of studying small groups in ethnography. Historical ethnography. St. Petersburg. (4). p.190.

[13] Maksimov, V.V., Nayden, E.V., \& Serebrennikova, A.N. (2010). The conceptual core of university discourse. Bulletin of the Tomsk Polytechnic University. Engineering of Georesources, 317 (6).

[14] Tishkov, V.A. (2003). Requiem for Ethnicity: Studies in Socio-Cultural Anthropology. Moscow. Science. p.544.

[15] Tolstoy N.I. (2001). Ethnolinguistics in the field of humanitarian disciplines. Russian literature: Anthology. Moscow. Academy. p.320.

[16] Холматова, Д. А. (2020). Theoretical Aspects of Studying Ethnography as a Scientific Discipline. Bulletin of Science and Practice, 6(8), 312-316. https://doi.org/10.33619/2414- 2948/57/39

[17] Yushmanov, N.V. (2015). Elements of international terminology: a reference dictionary. Moscow. Science. p.72.

[18] Yakubov, I.M. (1991). Analysis of the equivalence of the linguistic terms of the 
Russian and Uzbek languages (Doctoral dissertation, Tashkent State University).

[19] Khamrakulov, F. (2010). Management in Russian and Uzbek languages. Scientific notes of the Khujand State University named after academician B. Gafurov. Humanities, (1 (21)).

[20] Vasiliev Nikolay Leonidovich, \& Popovich Tanya (2015). The integrative potential of the university course "History of the Russian literary language". Integration of Education, 19 (3 (80)), 8590.

[21] Maksimov, V.V., Nayden, E.V., \& Serebrennikova, A.N. (2010). The conceptual core of university discourse. Bulletin of the Tomsk Polytechnic University. Engineering of Georesources, 317 (6). 